transition of phenanthrene, occurring at $2925 \mathrm{~A}$. in iso-octane $e^{7}$, shows a marked degree of resolution, and Clar has assigned to it a distinct transition. The freeelectron model of Platt does not suggest that this is so; but this interesting phenomenon is worthy of further study.

The three transitions of the hydrocarbon naphthalene are more in accord with the sequences of the angular system, and suggest that this hydrocarbon is not significantly polyacene in character. On general grounds, it is optimistic to suppose that benzene might be the first member of any of the sequences, and this is confirmed. It may be significant that only in the forbidden ${ }^{1} L_{b}$ transition does it exhibit the behaviour of an angularly condensed hydrocarbon.

An almost exact parallel to the correlation between molecular weight and band position in $\mathrm{cm}^{-1}$ is obtained when the latter entity is related to the number of resonating carbon atoms in the various molecules considered. This must necessarily be so, since a high degree of proportionality exists between the molecular weight and the number of resonating carbon atoms, excepting those aromatic hydrocarbons of low molecular weight.

Since the hydrogen atoms of these molecules play a definite part in determining the precise position of the absorption bands of polynuclear aromatic hydrocarbons, by virtue of the finite polarizability of the $\sigma$-type $\mathrm{C}-\mathrm{H}$ bonds, it has seemed desirable to take them into account. This is most conveniently accomplished by considering the overall molecular weight of the hydrocarbon in question, rather than the number of resonating carbon atoms contained in the structure.

169 Reigate Avenue,

Sutton, Surrey. Dec. 17.

"Clar, E., "Aromatische Kohlenwasserstoffe" (Verlag Julius Springer, Berlin, 1941).

2 Mayneord, W. V., and Roe, E. M. F., Proc. Roy. Soc., A, 152, 299

${ }^{3}$ Jones, R. N., Chem. Rev., 32, 1 (1942) ; J. Amer. Chem. Soc., 67, 2127 (1945).

4 Various papers presented at the Faraday Society Discussion, "Spectroscopy and Molecular Structure", 1950.

'Baldock, G. R., Proc. Phys. Soc., A, 63, 585 (1950).

6 Platt, J: R., J. Chem. Phys., 17, 484 (1949).

"Maddams, W. F., and Schnurmann, R., J. Chem. Phys., 17, 108 (1949).

\section{FOREST PRODUCTS RESEARCH} REPORT FOR 1949

$\mathrm{T}$ HE latest report of the Forest Products Research Board*, which is for the year 1949, affords a good illustration of the increasing activities of the Forest Products Research Laboratory at Princes Risborough and of the many different forms of research that are now being carried out there. These include problems in connexion with timber or timber utilization in the fields of the botanical sciences (wood structure and physiology), mycology, entomology, chemistry, physics, timber mechanics and seasoning, woodworking and wood preservation. In spite of the extensive research programme, advisory work continues to be an important feature, nearly thirteen thousand inquiries being received annually. These are not confined to the British Isles, and assistance is often given to Commonwealth countries.

* Department of Scientific and Industrial Research. Report of the Forest Products Research Board with the Report of the Director of Forest Products Research for the Year 1949. Pp. $50+8$ plates. (London: H.M.S.O., 1951.) 28. 6d. net.
The testing of British Colonial timbers continues to receive high priority and to engage much of the attention of the specialist sections. These have included timbers now being exploited in Nigeria, the Gold Coast, Uganda, East Africa, British Guiana and Malaya. A pilot plant for investigating the possibility of utilizing tropical timbers for hard-board manufacture has been established.

An interesting problem has been that concerned with the utilization of 'Rhodesian teak' (Baikioea plurijuga) in Northern Rhodesia. Large areas of Rhodesian teak forest destroyed in the past contain a considerable volume of dead standing trees or halfburnt logs (estimated at several million cubic feet). This timber is of a dry, hard and abrasive nature and has been left almost untouched by sawmillers as too troublesome to saw. It was. found that this refractory timber could be worked satisfactorily by the use of hard-tipped inserted saw-teeth, that is, teeth tipped with 'Stellite'-a very hard alloy of cobalt, chromium and tungsten. The 'Stellite' tipped teeth gave more than six times the output of ordinary teeth, in some instances as much as ten times, before sharpening was necessary. An improved method of preparing the teeth and depositing the 'Stellite' in the mill was evolved. The cost of 'Stelliting' was counterbalanced by the reduced consumption of teeth. Possibly this process may well prove advantageous with hardwoods in other countries that are found to be severe on saw-mill equipment.

Other sawing studies have been carried out. The stroboscopic method has been successfully employed in studying the action of cutting edges on timber. A technique has been evolved for using either the strobo-torch or high-speed photography for observing the behaviour of sawdust in the tooth gullets of a circular saw. One side of the saw is in contact with a toughened glass window, through which the quantity and path of the sawdust can be either continuously observed or photographed while the saw is in operation at different speeds. This method obviates the errors caused by having to stop the saw and open up the wood for inspection of the sawdust in the gullets.

Most of the mycological inquiries received referred to the treatment or prevention of dry rot (Merulius lacrymans) in buildings. The number of inquiries about the cause of decay in wooden boats and ships indicates that naval architects and shipwrights are becoming increasingly interested in this problem. Work has been carried out in co-operation with the Building Research Station, Garston, near Watford, on fungicidal renderings for application to walls infected with dry rot. It has been found that the addition of cuprous oxide to a magnesium oxychloride cement makes it sufficiently toxic to prevent growth of the fungus when the rendering is applied. Paints and renderings based on zinc oxychloride have also proved toxic to the fungus.

It has long been known that the wooden slats in water-cooling towers are very subject to decay. Hitherto this has been regarded as being caused solely by the action of the heated water. A study of the fungal flora showed that none of the recognized destroyers of wood was present. One which destroys cellulose was, however, isolated. It is considered that fungi may play a part as secondary agents in increasing the rate of deterioration - an interesting discovery to both the mycologist and the industrial user. Other mycological studies have been concerned. 
with the physiology of wood-destroying fungi, sapstain investigations and laboratory testing of wood preservatives.

In the entomological field the prevalence of pinholes in tropical hardwoods caused by beetles of the families Platypodidæ and Scolytidæ has attracted much attention. The use of some of the newer insecticides, applied by brush or spray to the logs immediately after felling in order to avoid infestation, is now being employed or tried. Investigations have been continued on Lyctus powder-post beetles, the common furniture beetle (Anobium punctatum), the death-watch beetle (Xestobium rufovillosum), and the house longhorn beetle (Hylotrupes bajulus).

Work on the durability of plywood adhesives has been continued in collaboration with the Ministry of Supply, to include tropical tests at Port Harcourt, Nigeria, where plywood can be exposed to conditions ranging from full sun to sheltered storage. Samples of plywood and built-up units were also placed in a 70-ft. torpedo boat for marine tests in H.M.S. Hornet at Gosport to investigate the durability of many types of glue. More than five thousand samples have been made for these plywood experiments.

In connexion with timber mechanics, interesting results are recorded in regard to the wearing qualities of some of the newer tropical hardwoods as wood block or strip flooring. 'Muhimbi' (Cynometra alexandri) and 'musine' (Croton megalocarpon) from East Africa showed promise as substitutes for maple for heavy-duty flooring, especially 'muhimbi'. 'Krabak' (Anisoptera spp.) from Siam was satisfactory for light-duty flooring as in domestic and other buildings. 'Kokrodua' (Afrormosia sp.) from West Africa was satisfactory as a substitute for Burma teak for ship's decking as regards resistance to wear.

Much of the work in wood bending has been concerned with the bending properties of oversea timbers in the hope that some may be suitable substitutes for the commonly used bending-woods such as beech and ash that are now in short supply. Of twenty-five species tested, none was equal to beech in bending properties. It is understood that some notable advances in wood bending have been made at Princes Risborough since the report was written.

Research on pruning has also fallen within the purview of the Forest Products Laboratory, a senior officer having visited Germany to study the effects of the pruning of conifers on the reduction of knots in the wood. Good reasons exist for pruning Douglas fir, and special quality Scots pine, but on the Continent green pruning of spruce is associated with the admittance of fungal decay.

\section{CARNEGIE TRUST FOR THE UNIVERSITIES OF SCOTLAND}

\section{ANNUAL REPORT FOR 1950-51}

$\mathrm{T}$ HE fiftieth annual report of the Carnegie Trust for the Universities of Scotland* covers the academic year 1950-51, completing fifty years work since the trust deed was signed by $\mathrm{Mr}$. Carnegie on June 7, 1901. The main topic discussed in the report

* Carnegie Trust for the Universities of Scotland. Fiftieth Annual Report (for the Year 1950-51) submitted by the Executive Committee Carnegie Trust, 1952.) is that of assistance given to students towards their class-fee payments, on which the executive committee of the Trust entertains some anxiety. It appears to the committee that the function of the Trust was narrowed considerably by the Education (Scotland) Act of 1946, and that for fee assistance the committee needs to consider only those who were not recipients of education authority bursaries. On this basis, only $£ 7,836$ (to 370 students) was paid out in 1950-51; but a further review of the whole situation has led the committee to conclude that, where the amount of the bursary together with other factors, such as the family resources and the cost of living away from home, appear to warrant it, it would be justified, if it so desires, in continuing to give assistance with the class fees to those holding bursaries from the education authorities as well as to those who have no such aid. From the beginning of the academic year 1951-52, the executive committee has modified its regulations accordingly; but no return to the original scale is contemplated in view of the substantial bursaries now awarded by the authorities.

This development will affect the ability of the committee to develop still further its schemes for postgraduate study and research, to which during $1950-51$ a record amount of $£ 38,170$ was allotted. The first list of recommendations for awards under the new schemes initiated in October 1950 convinced the committee that the lower age-limit should be thirty years and that awards in any one year should be restricted to ten at most. For 1950-51, two awards were made for cancer and dermatological research in the United States; two in geography, one recipient going to the north-east Mediterranean littoral and the other to Cape Breton Island; one in botany at the University of California ; two in literature, for study at Yale University and in Germany, respectively; and one for investigation into racial relationships in southern Africa. A maximum of $£ 6,000$ is proposed for this aspect of the research scheme. The demands for expensive items of equipment by workers in many fields of science and medicine have caused some embarrassment, and the committee has been compelled to require all individual applications to the Trust of this type to be submitted through the authorities of the university or college from which application is made.

During the first few years of the eighth quinquennial (1947-52), supplements to the extent of $\mathfrak{£ 6 7 , 0 0 0}$ were made to universities and colleges; but the "Abstract of Grants and Payments in the Accounts" appended to the report shows considerable undrawn balances, totalling $£ 74,940$. The University of Glasgow has steadily taken up the grant in assisting in payments for the final portion of the Chemistry Institute. The executive committee notes that the amount of $£ 1,033$ repaid by former beneficiaries was the lowest recorded in the past thirty years. Appendixes to the report deal with the work of investigators under the research scheme during the academic year 1950-51, and list publications by fellows, scholars and recipients of grants received since September 30, 1950, as well as papers assisted by a grant of $£ 500$, and fellowships, scholarships and grants awarded for the year 1951-52. Statistics of assistance to students during 1950-51, with comparative tables for 1949-50 and 1950-51, are included, as well as details of the modified scheme for the endowment of postgraduate study and research. 